\title{
Effects of bovine leukemia virus infection on milk neutrophil function and the milk lymphocyte profile
}

\author{
Alice Maria Melville Paiva Della Libera ${ }^{*}$, Fernando Nogueira de Souza², Camila Freitas Batista ${ }^{1}$, \\ Bruna Parapinski Santos', Luis Fernando Fernandes de Azevedo, Eduardo Milton Ramos Sanchez ${ }^{3}$, \\ Soraia Araújo Diniz², Marcos Xavier Silva², João Paulo Haddad² and Maiara Garcia Blagitz ${ }^{1}$
}

\begin{abstract}
The effects of bovine leukemia virus (BLV) on the immune response have been extensively investigated; however, its effects on mammary gland immunity are only speculative. Although BLV has a tropism for B cells, it can affect both adaptive and innate immunities because these systems share many effector mechanisms. This scenario is the basis of this investigation of the effects of BLV on mammary gland immunity, which is largely dependent upon neutrophilic functions. Thus, the present study sought to examine neutrophilic functions and the lymphocyte profile in the milk of naturally BLV-infected cows. The viability of the milk neutrophils and the percentage of milk neutrophils that produced reactive oxygen species (ROS) or phagocytosed Staphylococcus aureus were similar between BLV-infected and BLV-uninfected dairy cows. Furthermore, the expression of CD62L and CD11b by the milk neutrophils and the percentage of milk neutrophils $\left(\mathrm{CH}_{138^{+}}\right.$cells) that were obtained from the udder quarters of the BLV-infected cows were not altered. Conversely, the median fluorescence intensity (MFI) representing intracellular ROS production and the phagocytosis of $S$. aureus, the expression of CD44 by the milk neutrophils and the percentage of apoptotic B cells were lower in the milk cells from BLV-infected dairy cows, particularly those from animals with persistent lymphocytosis (PL). The lymphocyte subsets were not different among the groups, with the exception of the percentage of $\mathrm{CD}^{-} / \mathrm{CD} 11 \mathrm{~b}^{-} \mathrm{B}$ cells, which was higher in the milk cells from BLV-infected cows, particularly those with PL. Thus, the present study provides novel insight into the implications of BLV infection for mammary gland immunity.
\end{abstract}

\section{Introduction}

Bovine leukemia virus (BLV) is a member of the Retroviridae family and the Deltaretrovirus genus that is genetically and structurally similar to the primate T-lymphotropic viruses types 1-5 (i.e., HTLV-1 to 4). Although BLV has been successfully eradicated in some regions of Europe, it is among the most widespread livestock pathogens in many countries, particularly in dairy herds. BLV infections in cattle may remain clinically silent or present as persistent lymphocytosis (PL); more rarely, BLV infection may result in B cell lymphoma. PL is characterized by a chronic elevation in the number of circulating $B$

\footnotetext{
* Correspondence: dellalibera@usp.br

'Departamento de Clínica Médica, Faculdade de Medicina Veterinária e Zootecnia, Universidade de São Paulo, Av. Prof. Dr. Orlando Marques de Paiva, 87, Cidade Universitária, São Paulo 05508-270, Brazil

Full list of author information is available at the end of the article
}

lymphocytes and is found in approximately $20-30 \%$ of BLV-infected cattle [1].

Various studies have investigated the effects of BLV infection on lymphocyte subsets [1-8], neutrophil functions [9-14] and B cell viability [15-22]. All of these studies evaluated these parameters in the blood, and therefore, the effects of BLV infection on the lymphocyte subsets, neutrophil functions and B cell viability in milk are only speculative. However, mastitis [23-30] and decreased milk production [31-35] have been associated with BLV infection, particularly in BLV-infected cows with PL [31] and high-performing infected dairy herds [35]. These findings prompted an investigation into the effects of BLV, which is a B cell tropic virus $[1,6,15]$, on mammary gland immunity, which is largely dependent upon neutrophil functions and recruitment. Notably, the impact of some chronic diseases with low lethality, such 
as BLV infection, may be underestimated because they may be associated with comorbidities, such as mastitis, which is the most costly dairy cattle disease. This disease threatens the image of the dairy sector because of animal welfare issues and issues related to milk quality and public health due to increased risks of antimicrobial residues and the emergence of resistant bacteria. A better understanding of the implications of BLV infection on mammary gland immunity is critical for controlling mastitis and facilitating the strict control of these infections to improve dairy cattle productivity. Thus, the present study sought to explore milk lymphocyte subsets, neutrophil functions and B cell viability from naturally BLV-infected cows.

\section{Materials and methods}

\section{Experimental design and collection of samples}

The present study used 57 quarters of the mammary glands of 19 dairy cows in a commercial herd, at different lactation stages. Due to the effects of bacterial mastitis pathogens on neutrophil function [36-40], the following exclusion criteria were applied: 1 ) bacteriologically positive quarters; 2) quarters with abnormal secretions in the strip cup test; and 3) quarters with high somatic cell counts (SCCs) based on the previously proposed threshold for SCC $[41,42]$.

The sera of all of the animals were tested for BLV using an agar gel immunodiffusion (AGID) assay (Tecpar', Curitiba, Brazil) and an ELISA (VMRD Pullman Inc., Pullman, WA, USA, cat. number 284-5), using gp51 as the antigen. These animals were divided uniformly into the following three groups according to the sera test results: negative for BLV infection according to the AGID and ELISA assays and lacking hematological alterations [43] (healthy; $n=8$; 24 quarters); positive for BLV according to both tests and lacking hematological alterations [43], which is commonly referred to as aleukemic (AL; $n=6 ; 16$ quarters); and positive for BLV according to both tests and exhibiting PL ( $n=5 ; 17$ quarters). The BLV-infected cattle were classified as having PL when their lymphocyte counts exceeded $1 \times 10^{4} \mathrm{~mL}^{-1}$ and their leukocyte counts exceeded $1.5 \times 10^{4} \mathrm{~mL}^{-1}$ as established by Thurmond et al. [44]. One hundred ten days after the first sampling for the serodiagnosis of BLV, additional blood samples for the hematological procedures and serodiagnoses of BLV were collected to confirm the persistence of lymphocytosis. At this time (110 days after the first sampling), milk cells for the SCC, bacteriological analysis and flow cytometry analysis to determine neutrophil function and lymphocyte profile were also collected.

First, the strip cup test was performed to determine the presence of clots or flakes or otherwise obviously abnormal secretions. Then, predipping was performed, using one towel for each teat. After discarding the first three milk streams, the ends of the teats were scrubbed with $70 \%$ ethanol using a piece of cotton, and single milk samples from the individual mammary quarters were aseptically collected in sterile vials for the bacteriological analysis. Finally, milk samples for the SCC and the evaluation of neutrophilic function and lymphocyte profile were collected. The samples were maintained at $4{ }^{\circ} \mathrm{C}$ until they arrived at the laboratory. The milk samples for the bacteriological analysis were stored at $-20{ }^{\circ} \mathrm{C}$ for a maximum of 30 days until the analysis.

Subsequently, each sample was codified and randomized, and further analyses were performed in which the researcher was blinded to the BLV status of the animal from which the sample was drawn. This research complied with the Ethical Principles for Animal Research and was approved by the Bioethics Commission.

\section{Hematological procedures}

The total leukocyte counts were determined using an automated cell counter (ABX VET ABC, Horiba ABX Diagnostic $^{\circ}$, Montpellier, France). The differential leukocyte counts were performed using routine smears.

\section{Bacteriological analysis}

The bacteriological analysis was performed by culturing $0.01 \mathrm{~mL}$ of each milk sample on $5 \%$ sheep blood agar plates. The plates were incubated for $72 \mathrm{~h}$ at $37^{\circ} \mathrm{C}$, followed by Gram staining, observation of colony morphologies and biochemical testing [45]. A milk sample was considered to be culture-positive when the growth of $\geq 3$ colonies was detected, with the exception of animals with Staphylococcus aureus or Streptococcus agalactiae infections in their quarters, which were considered to be culture-positive when the growth of $\geq 1$ colony was detected $[46,47]$.

\section{Determination of SCC}

The milk samples for SCC determination were collected in $40-\mathrm{mL}$ vials containing microtablets of the preservant agent bronopol (2-bromo-2-nitropane-1,3-diol). Subsequently, the SCC were performed using the Somacount 300 automated somatic cell counter (Bentley Instruments, Chaska, MN, USA).

\section{Separation of milk cells}

The separation of the milk cells was performed as described by Koess and Hamann [48]. Briefly, $1 \mathrm{~L}$ of milk was diluted with $1 \mathrm{~L}$ of phosphate-buffered saline (PBS; $\mathrm{pH} 7.4 ; 1.06 \mathrm{mM} \mathrm{Na} \mathrm{HPO}_{4}, 155.17 \mathrm{mM} \mathrm{NaCl}$ and $2.97 \mathrm{mM} \mathrm{Na}_{2} \mathrm{HPO}_{4} \cdot 7 \mathrm{H}_{2} \mathrm{O}$ ). After centrifugation at $1000 \times g$ for $15 \mathrm{~min}$, the cream layer and supernatant were discarded. The cell pellet was then washed once using $30 \mathrm{~mL}$ of PBS and centrifuged at $400 \times g$ for $10 \mathrm{~min}$. The cells were resuspended in $1 \mathrm{~mL}$ of RPMI-1640 nutritional 
medium (R7638, Sigma Aldrich, USA) supplemented with 10\% fetal bovine serum (Cultilab, Brazil) and counted using a Neubauer chamber. Cell viability was first evaluated by trypan blue exclusion. The milk cells were then diluted with nutritional medium containing $10 \%$ fetal bovine serum to a concentration of $2 \times 10^{6}$ viable cells $\mathrm{mL}^{-1}$.

\section{Enumeration of lymphocyte subpopulations}

The cells were washed with PBS and stained to detect the combination of $\mathrm{CD} 3, \mathrm{CD} 4$ and $\mathrm{CD} 8$, the combination of $\mathrm{CD} 3, \mathrm{CD} 4$ and $\mathrm{CD} 25$ and the combination of CD21, CD5 and CD11b following incubation with the primary antibodies (Abs) for $30 \mathrm{~min}$ at room temperature. The identification of lymphocyte subsets was based on their cytoplasmic granularities and mean fluorescence intensities following a two-step fluorescent immunolabeling protocol using primary anti-bovine monoclonal Abs and secondary Abs coupled to long-wavelength fluorescent probes. Thus, the following primary monoclonal antibodies (mAbs) directed against bovine lymphocytes were used: mouse IgG1 anti-bovine CD3 (T lymphocytes, MM1A, VMRD Pullman Inc. Corp ${ }^{\circ}$, mouse IgG2a antibovine CD4 (IL-A11, VMRD Pullman Inc. Corp ${ }^{\circ}$, mouse IgM anti-bovine CD8 $\alpha$ (BAQ111A, VMRD Pullman Inc. Corp ${ }^{\circ}$ ), mouse IgG3 anti-bovine CD25 (LCTB2A; VMRD Pullman Inc. Corp ${ }^{\circ}$ ), mouse IgM anti-bovine CD21 (B lymphocytes, BAQ15A, VMRD Pullman Inc. Corp ${ }^{\circ}$, mouse IgG2a anti-bovine CD5 (B29A, VMRD Pullman Inc. Corp ${ }^{\circ}$ ) and mouse IgG1 anti-bovine CD11b (MM12A, VMRD Pullman Inc. Corp ${ }^{\circ}$ ). After washing with PBS, the cells were incubated for $30 \mathrm{~min}$ at room temperature with the following secondary Abs: goat anti-mouse IgG1 conjugated to phycoerythrin-Cy5 (PE-Cy5) (M32018; Invitrogen, Carlsbad, CA, USA), goat anti-mouse IgM conjugated to fluorescein isothiocyanate (FITC) (M31501, Invitrogen), goat anti-mouse IgG2a conjugated to phycoerythrin (PE) (M32204, Invitrogen) and goat anti-mouse IgG3 conjugated to FITC (M32701, Invitrogen). The cells were then washed with PBS and immediately analyzed using flow cytometry. A total of 20000 milk cells, excluding most of the cellular debris, was examined per sample. The FlowJo software (TreeStar Inc., Ashland, OR, USA) was used to analyze the data. The results were corrected for autofluorescence content, which was defined as the fluorescence that was associated with the non-labeled freshly isolated milk cells from the same cow.

\section{Identification of neutrophils}

Milk neutrophils were differentiated from other cells by indirect fluorescent labeling. The cells were incubated with an unlabeled primary monoclonal anti-bovine granulocyte antibody (anti-CH138A, VMRD Pullman Inc. Corp $^{\circ}$ ) for $30 \mathrm{~min}$ at room temperature. Next, $1 \mathrm{~mL}$ of PBS was added to the cell suspension, which was centrifuged at $400 \times g$ for $8 \mathrm{~min}$. Finally, a labeled secondary Ab was added, and the sample was incubated for $30 \mathrm{~min}$ at room temperature in the dark to visualize the bound $\mathrm{CH} 138 \mathrm{~A}$. The neutrophils were identified using flow cytometry based on the cells' cytoplasmic granularities and $\mathrm{CH} 138 \mathrm{~A}$ positivities as previously described $[40,49]$. The labeled secondary mAbs included allophycocyanin- (APC; M31505, Invitrogen), FITC- (M31501, Invitrogen) or PE-conjugated (M31504, Invitrogen) goat anti-mouse IgM mAb. A total of 20000 milk cells, excluding most of the cellular debris, was examined per sample. The FlowJo software (TreeStar Inc., Ashland, OR, USA) was used to analyze the data. The results were corrected for autofluorescence content, which was defined as the fluorescence that was associated with the non-labeled freshly isolated milk cells from the same cow.

\section{Detection of apoptosis by flow cytometry}

The death of neutrophils $\left(\mathrm{CH} 138^{+}\right)$and $\mathrm{B}$ cells $\left(\mathrm{CD} 21^{+}\right)$ was assessed using dual labeling with an annexin $\mathrm{V}$ antibody and propidium iodide (PI; K2350, APOPTEST-FITC, Dako Cytomation, The Netherlands) and flow cytometric analyses as previously described $[40,49]$. Briefly, $2 \times 10^{5}$ viable milk cells were suspended in $100 \mu \mathrm{L}$ of binding buffer (10 mM HEPES, $150 \mathrm{mM} \mathrm{NaCl}, 1 \mathrm{mM} \mathrm{MgCl}$ and $1.8 \mathrm{mM} \mathrm{CaCl}_{2}$ ) containing anti-annexin V-FITC antibody and incubated at room temperature for $20 \mathrm{~min}$ in the dark. Immediately before flow cytometry analysis, $5 \mu \mathrm{L}$ of a $250 \mu \mathrm{g} / \mathrm{mL}$ PI solution was added. Next, the neutrophils were labeled using $\mathrm{mAbs}$ as described above.

To analyze the data, scatter plots were generated for the gated neutrophils or B cells. The living, nonapoptotic cells were negative for both FITC-labeled anti-annexin V and PI. The cells that were positive for FITC-labeled antiannexin $\mathrm{V}$ but negative for PI were classified as apoptotic cells $[40,49]$. The necrotic subpopulation was excluded from the analysis [49]. A total of 20000 milk cells, excluding most of the cellular debris, was examined per sample. The FlowJo software (TreeStar Inc., Ashland, OR, USA) was used to analyze the data.

\section{Intracellular reactive oxygen species production}

Intracellular reactive oxygen species (ROS) production was assessed by flow cytometry using $2^{\prime}, 7^{\prime}$-dichlorofluorescein diacetate (DCFH-DA) as a probe [50]. Briefly, $2 \times 10^{5}$ viable milk cells from each quarter that were previously assessed by trypan blue exclusion were incubated at $37^{\circ} \mathrm{C}$ for 30 min with $0.3 \mu \mathrm{M}$ DCFH-DA (D6883, Sigma Aldrich, St. Louis, MO, USA).

The intracellular $2^{\prime}, 7^{\prime}$-dichlorofluorescein (DCF) fluorescence of the neutrophils was determined by flow cytometry using an excitation wavelength of $488 \mathrm{~nm}$. DCFH-DA, which is a cell-permeable, nonfluorescent probe, is converted to DCF by ROS in a dose-dependent 
manner, resulting in fluorescence emission. The green fluorescence of DCF was detected at 500-530 nm.

The percentage of neutrophils producing ROS was calculated as the number of fluorescent neutrophils divided by the total neutrophil count and multiplied by 100 . The median fluorescence intensity (MFI) of ROS production was estimated from the median of DCF fluorescence divided by the number of neutrophil that produced ROS [40]. For this assay, 10000 gated neutrophils were examined per sample. The FlowJo software (TreeStar Inc., Ashland, USA) was used to analyze the data. The results were corrected for autofluorescence content, which was defined as the fluorescence that was associated with the non-labeled freshly isolated milk cells from the same cow.

\section{Preparation of PI-labeled bacteria}

PI-labeled Staphylococcus aureus (ATCC 25923) was prepared as proposed by Hasui et al. [50] with some modifications. Briefly, S. aureus was cultured for $18 \mathrm{~h}$ at $37{ }^{\circ} \mathrm{C}$ on brain-heart infusion agar. Subsequently, the bacteria were heat-killed by incubation at $60{ }^{\circ} \mathrm{C}$ for $30 \mathrm{~min}$, after which they were washed three times using a sterile saline solution $(0.9 \% \mathrm{NaCl})$. The bacterial density was adjusted to an absorbance of 2.50 at $620 \mathrm{~nm}$, yielding approximately $2.4 \times 10^{9}$ bacteria $\mathrm{mL}^{-1}$, as previously described [50]. The bacteria were then labeled using a 5\% PI (P4170, Sigma Aldrich, St. Louis, MO, USA) solution for $30 \mathrm{~min}$ at room temperature. The fluorescent bacteria were washed three times and suspended in PBS containing $5 \mathrm{mM}$ glucose and $0.1 \%$ gelatin, and aliquots were stored at $-80{ }^{\circ} \mathrm{C}$. Thereafter, the PI labeling of the bacteria was confirmed by flow cytometry.

\section{Phagocytosis assay}

The phagocytosis assay was performed using flow cytometry of PI-labeled S. aureus as previously described by Hasui et al. [50]. Briefly, $2 \times 10^{5}$ viable milk cells were incubated with $100 \mu \mathrm{L}$ of heat-killed, PI-labeled $S$. aureus and $900 \mu \mathrm{L}$ of PBS for $30 \mathrm{~min}$ at $37{ }^{\circ} \mathrm{C}$. Subsequently, $2 \mathrm{~mL}$ of $3 \mathrm{mM}$ EDTA was added, and after centrifugation at $400 \times g$ for $10 \mathrm{~min}$, the leukocytes were resuspended in $300 \mu \mathrm{L}$ of PBS and analyzed by flow cytometry.

The percentage of neutrophils that phagocytized the bacteria was equal to the number of fluorescent neutrophils divided by the total neutrophil count and multiplied by 100 . The MFI of $S$. aureus phagocytosis was estimated from the median value of PI fluorescence divided by the number of neutrophils that phagocytized $S$. aureus [40]. At least 20000 cells were examined per sample. The Flow Jo Tree Star Software (TreeStar Inc., Ashland, OR, USA) was used to analyze the data.

\section{Expression of L-selectin, $\beta_{2}$-integrin and CD44}

The identification of neutrophils expressing L-selectin (CD62L), the $\beta$-chain of $\beta_{2}$-integrin (CD11b) and one of the three endothelial-selectin (E-selectin) ligands (CD44) was performed by flow cytometry using the following mAbs: a FITC-conjugated mouse anti-bovine CD62L (MCA1649F, AbDSerotec, Oxford, England), a primary mouse IgG1 anti-CD11b mAb (MM12A, Pullman Inc. Corp ${ }^{\circ}$ ), a phycoerythrin-Cy5 (PE-Cy5)-conjugated goat anti-mouse IgG1 Ab (M32018, Invitrogen), a primary mouse IgG3 anti-CD44 mAb (BAG40A, Pullman Inc. Corp $^{\circ}$ ) and an FITC-conjugated goat anti-mouse IgG3 $\mathrm{Ab}$ (M32701, Invitrogen). First, dot plots of gated neutrophils $\left(\mathrm{CH}_{\left.138 \mathrm{~A}^{+}\right)}\right.$were generated as previously described. The neutrophils were identified as previously described. Then, unlabeled primary mAbs that were directed against $\mathrm{CD} 11 \mathrm{~b}$ and $\mathrm{CD} 44$ were added to the cell suspension and incubated for $30 \mathrm{~min}$ at room temperature. The isolated milk cell suspension was centrifuged at $400 \times g$ for $8 \mathrm{~min}$, and a labeled CD62L mAb and secondary labeled mAbs for the detection of the anti$\mathrm{CD} 11 \mathrm{~b}$ and -CD44 Abs were added. Finally, the isolated milk cells were incubated for $30 \mathrm{~min}$ at room temperature in the dark to allow for the visualization of cells expressing CD62L, CD11b and CD44. We chose the relative MFI because this parameter was much more discriminating compared with the percentage of positive cells. The MFI provides an accurate measurement of the brightness of the stained cells and is thus an indicator of the number of receptors per cell [51]. For this assay, 10000 gated neutrophil cells were examined per sample. The Flow Jo Tree Star Software (TreeStar Inc., Ashland, OR, USA) was used to analyze the data.

\section{Statistical analyses}

First, the distributions of all of the variables were examined using normal probability plots obtained using the Shapiro and Wilk tests. The data were analyzed using a multivariate analysis of variance. Then, the Kruskal-Wallis and Mann-Whitney tests were applied. The model considered the quarters and the cows to be nested within the cows. The statistical analyses were performed using the STATA statistical software version 12 (Stata Corp., College Station, Texas, USA). The results are reported as the mean \pm standard deviation. Significance was set at $P \leq 0.05$.

\section{Results}

The results are summarized in Tables 1, 2 and 3. The SCC, lactational status and parity (data not shown) values did not differ among the groups. Here, we found that BLV infection detrimentally affected some important milk neutrophilic functions. For instance, the MFI that represented the amount of intracellular ROS production by the milk 
Table 1 Characteristics of neutrophils in the milk of healthy and bovine leukemia virus (BLV)-infected cows

\begin{tabular}{|c|c|c|c|}
\hline Group/Variable & Negative $(n=24)$ & $\mathrm{AL}(n=16)$ & $\mathrm{PL}(n=17)$ \\
\hline $\mathrm{CH} 138^{+}(\%)$ & $13.72 \pm 14.91^{\mathrm{a}}$ & $8.89 \pm 9.72^{a}$ & $11.88 \pm 15.34^{\mathrm{a}}$ \\
\hline Annexin $\mathrm{V}^{-} / \mathrm{PI}^{-}(\%)$ & $30.74 \pm 12.92^{\mathrm{a}}$ & $39.05 \pm 16.06^{\mathrm{a}}$ & $24.97 \pm 16.01^{\mathrm{a}}$ \\
\hline Annexin $\mathrm{V}^{+} / \mathrm{PI}^{-}(\%)$ & $39.50 \pm 14.48^{a}$ & $37.03 \pm 21.92^{\mathrm{a}}$ & $39.27 \pm 19.64^{\mathrm{a}}$ \\
\hline ROS production (\%) & $54.91 \pm 22.92^{\mathrm{a}}$ & $68.20 \pm 21.85^{a}$ & $69.98 \pm 15.39^{\mathrm{a}}$ \\
\hline Intensity of ROS production (MFI) & $2069 \pm 1008^{\mathrm{a}}$ & $1603 \pm 585.7^{b}$ & $865.6 \pm 447.3^{c}$ \\
\hline S. aureus phagocytosis (\%) & $63.23 \pm 17.80^{\mathrm{a}}$ & $55.11 \pm 20.88^{\mathrm{a}}$ & $58.84 \pm 15.21^{\mathrm{a}}$ \\
\hline Intensity of S. aureusphagocytosis (MFI) & $219.8 \pm 100.3^{a}$ & $211.2 \pm 80.77^{a}$ & $104.2 \pm 39.11^{b}$ \\
\hline CD44 expression (MFI) & $22.03 \pm 22.65^{a}$ & $1.07 \pm 0.18^{b}$ & $1.03 \pm 0.09^{b}$ \\
\hline CD62L expression (MFI) & $13.45 \pm 15.41^{\mathrm{a}}$ & $1.01 \pm 0.00^{\mathrm{a}}$ & $1.01 \pm 0.00^{\mathrm{a}}$ \\
\hline CD11b expression (MFI) & $755.8 \pm 344.6^{\mathrm{a}}$ & $633.3 \pm 555.0^{\mathrm{a}}$ & $843.7 \pm 334.9^{\mathrm{a}}$ \\
\hline
\end{tabular}

Different superscripted letters ${ }^{\mathrm{a}, \mathrm{b}, \mathrm{c}}$ within a row indicate significant differences $(P \leq 0.05)$ between the values. The results are shown as the mean \pm SD.

AL: aleukemic BLV-infected cows; PL: BLV-infected cows with persistent lymphocytosis; PI: propidium iodide; S. aureus: Staphylococcus aureus; ROS: reactive oxygen species; MFI: median fluorescence intensity.

neutrophils was lower for the BLV-infected cows, particularly those with PL, than for the uninfected cows. Furthermore, the MFI that represented the amount of S. aureus phagocytosis by the milk neutrophils was also the lowest for the PL group. Moreover, the level of CD44 expression by milk neutrophils from the BLV-infected dairy cows was lower than that of milk neutrophils collected from the uninfected cows (Table 1).

The lymphocyte subsets did not differ among the groups, with the exception of the percentage of $\mathrm{CD}^{-} / \mathrm{CD} 11 \mathrm{~b}^{-} \mathrm{B}$ cells, which was higher in the BLV-infected cows, particularly those with PL (Table 2). Furthermore, the percentage of apoptotic B cells was lower in the BLV-infected dairy cows (Table 3 ), particularly those with PL, than in the uninfected cows.

\section{Discussion}

It is not easy to precisely delineate innate immunity because it is intricately enmeshed with adaptive immunity, and the two systems share many effector mechanisms [37]. Thus, various viruses can affect the general functions of both innate and adaptive immunities. This phenomenon predisposes animals to different coinfections or superinfections and can increase the severity of infections $[25,28,30,52-55]$. As previously mentioned, the impact of some chronic diseases with low lethalities may be underestimated because of their associations with comorbidities. This scenario prompted an investigation into the effects of $\mathrm{BLV}$, which is a $\mathrm{B}$ cell tropic virus $[1,6,15]$, on mammary gland immunity, which is largely dependent on neutrophil function and recruitment [36-40].

Table 2 Percentage of lymphocyte subsets in the milk from healthy and bovine leukemia virus (BLV)-infected cows

\begin{tabular}{|c|c|c|c|}
\hline Group/Variables & Negative $(n=25)$ & $\operatorname{AL}(n=16)$ & $\mathrm{PL}(n=17)$ \\
\hline $\mathrm{CD3}^{+}$(T cells) $(\%)$ & $7.13 \pm 5.04^{a}$ & $10.46 \pm 9.30^{a}$ & $11.66 \pm 7.27^{\mathrm{a}}$ \\
\hline $\mathrm{CD4}^{+} / \mathrm{CD}^{-} \mathrm{T}$ cells (\%) & $1.32 \pm 1.19^{a}$ & $1.83 \pm 1.73^{\mathrm{a}}$ & $2.55 \pm 2.48^{\mathrm{a}}$ \\
\hline $\mathrm{CD4}^{-} / \mathrm{CD8}^{+} \mathrm{T}$ cells $(\%)$ & $3.15 \pm 2.57^{a}$ & $4.45 \pm 2.02^{\mathrm{a}}$ & $4.51 \pm 3.86^{a}$ \\
\hline $\mathrm{CD4}^{+} / \mathrm{CD}^{+} \mathrm{T}$ cells $(\%)$ & $0.41 \pm 0.36^{a}$ & $0.33 \pm 0.30^{a}$ & $0.23 \pm 0.19^{a}$ \\
\hline $\mathrm{CD}^{-} / \mathrm{CD}^{-} \mathrm{T}$ cells (\%) & $2.24 \pm 2.33^{a}$ & $3.84 \pm 5.74^{\mathrm{a}}$ & $4.38 \pm 3.87^{\mathrm{a}}$ \\
\hline $\mathrm{CD3}^{+}$(T cells) (\%) & $6.31 \pm 4.99^{\mathrm{a}}$ & $10.28 \pm 10.44^{a}$ & $11.06 \pm 6.81^{\mathrm{a}}$ \\
\hline $\mathrm{CD}^{+} / \mathrm{CD}^{2} 5^{-} \mathrm{T}$ cells (\%) & $1.38 \pm 1.32^{\mathrm{a}}$ & $1.84 \pm 1.67^{\mathrm{a}}$ & $2.70 \pm 2.46^{\mathrm{a}}$ \\
\hline $\mathrm{CD}^{-} / \mathrm{CD} 25^{+} \mathrm{T}$ cells (\%) & $0.06 \pm 0.04^{a}$ & $0.13 \pm 0.18^{\mathrm{a}}$ & $0.15 \pm 0.14^{a}$ \\
\hline $\mathrm{CD4}^{+} / \mathrm{CD}^{2} 5^{+} \mathrm{T}$ cells (\%) & $0.24 \pm 0.23^{a}$ & $0.21 \pm 0.29^{a}$ & $0.29 \pm 0.36^{a}$ \\
\hline$\overline{\mathrm{CD}^{-} / \mathrm{CD} 25^{-} \mathrm{T} \text { cells (\%) }}$ & $4.63 \pm 4.11^{a}$ & $8.11 \pm 8.58^{\mathrm{a}}$ & $7.92 \pm 4.62^{\mathrm{a}}$ \\
\hline${\mathrm{CD} 21^{+}(\mathrm{B} \text { cells) }(\%)}$ & $7.90 \pm 5.53^{\mathrm{a}}$ & $13.02 \pm 8.14^{\mathrm{a}}$ & $17.44 \pm 7.20^{\mathrm{a}}$ \\
\hline $\mathrm{CD5}^{+} / \mathrm{CD} 11^{-} \mathrm{B}$ cells (\%) & $0.87 \pm 0.88^{\mathrm{a}}$ & $0.71 \pm 0.45^{a}$ & $0.72 \pm 0.47^{\mathrm{a}}$ \\
\hline $\mathrm{CD5}^{-} / \mathrm{CD} 11^{+} \mathrm{B}$ cells (\%) & $3.84 \pm 4.01^{a}$ & $6.80 \pm 6.97^{a}$ & $8.59 \pm 5.15^{a}$ \\
\hline $\mathrm{CD5}^{+} / \mathrm{CD} 11^{+} \mathrm{B}$ cells (\%) & $0.85 \pm 0.78^{a}$ & $0.85 \pm 0.51^{a}$ & $1.01 \pm 0.66^{\mathrm{a}}$ \\
\hline$\overline{\mathrm{CD}^{-} / \mathrm{CD} 11^{-} \mathrm{B} \text { cells }(\%)}$ & $2.35 \pm 1.73^{a}$ & $4.67 \pm 3.26^{b}$ & $7.11 \pm 3.89^{c}$ \\
\hline
\end{tabular}

Different superscripted letters ${ }^{\mathrm{a}, \mathrm{b}, \mathrm{c}}$ within a row indicate significant differences $(P \leq 0.05)$ between the values. The results are shown as the mean \pm SD.

AL: aleukemic BLV-infected cows; PL: BLV-infected cows with persistent lymphocytosis. 
Table 3 Viability of B cells in milk from healthy and bovine leukemia virus (BLV)-infected cows.

\begin{tabular}{lccc}
\hline Group/Variables & Negative $(\boldsymbol{n}=\mathbf{2 5})$ & $\mathrm{AL}(\boldsymbol{n}=\mathbf{1 6})$ & $\mathrm{PL}(\boldsymbol{n}=\mathbf{1 7})$ \\
\hline Annexin $\mathrm{V}^{-} / \mathrm{PI}^{-}(\%)$ & $37.13 \pm 17.99^{\mathrm{a}}$ & $51.15 \pm 16.73^{\mathrm{a}}$ & $71.31 \pm 13.02^{\mathrm{a}}$ \\
\hline Annexin $\mathrm{V}^{+} / \mathrm{PI}^{-}(\%)$ & $55.72 \pm 17.59^{\mathrm{a}}$ & $31.22 \pm 18.43^{\mathrm{b}}$ & $12.35 \pm 6.44^{\mathrm{c}}$ \\
\hline
\end{tabular}

Different superscripted letters $\mathrm{s}^{\mathrm{a}, \mathrm{b}, \mathrm{c}}$ within a row indicate significant differences $(P \leq 0.05)$ between the values. The results are shown as the mean \pm SD AL: aleukemic BLV-infected cows; PL: BLV-infected cows with persistent lymphocytosis; PI: propidium iodide.

Neutrophils form the first line of cellular defense against invading pathogens [36-40] and are essential for the innate host defense against invading microorganisms. These cells eliminate pathogens by a process known as phagocytosis. During phagocytosis, neutrophils produce ROS to kill invading pathogens [36-40,56].

Apoptosis of bovine neutrophils implies impaired phagocytic and oxidative burst activities $[47,57,58]$. Neutrophil viability is closely related to neutrophil phagocytosis and oxidative burst activities [56,58]. Thus, the nonsignificant difference that was observed in neutrophil viability rates among the groups in this study may be related to the results for the percentage of neutrophils that produced ROS or phagocytosed S. aureus.

While the study size is limited, we observed a lower MFI representing the phagocytosis of $S$. aureus and the intracellular production of ROS by the milk neutrophils from the BLV-infected cows, particularly those with PL. BLV-infected cows with PL have higher proviral loads $[59,60]$ that are linked to lower levels of interferon (IFN) $-\gamma$ expression by peripheral blood mononuclear cells [7,61-63], which is regulated by many factors, such as the PD-1 $[7,62]$ and Tim-3/Gal-9 pathways [63]. IFN- $\gamma$ has a positive effect on bovine neutrophil phagocytosis and ROS production [64], and this characteristic together with the altered production of IFN- $\gamma$ by the peripheral blood mononuclear cells of BLV-infected cattle may explain our results regarding the deficient functions of the milk neutrophils. Consistent with our findings, Takamatsu et al. [11] found that most sera from leukemic cattle inhibit the phagocytosis of blood neutrophils.

In this study, no significant differences were observed in the levels of CD62L and CD11b expression by the milk neutrophils of BLV-infected cows. CD62L mediates the initial transient attachment of circulating granulocytes to the activated endothelium. The surface expression and rapid functional activation of Mac-1 (CD11b/ CD18) is essential for the subsequent granulocyte migration to the site of inflammation. Following activation, CD62L is shed from the cell surface by proteolysis, whereas the surface expression of Mac-1 is up-regulated [51]. Therefore, the migration of neutrophils across endothelial cells is almost completely dependent upon CD18, the $\beta$-chain of $\beta_{2}$ integrins and to a lesser extent on CD11b, which is one of the $\alpha$-chains of $\beta_{2}$ integrins [36].

Further, we found decreased levels of CD44 expression in the milk neutrophils from the BLV-infected dairy cows. CD44 was identified as one of the three endothelial-selectin ligands that are present on neutrophils, which are responsible for hindering their movement and activating their rolling. However, CD44 is required, but not essential, for neutrophil extravasation during inflammation [65]. CD44 is also regarded as a competent phagocytic receptor that efficiently mediates pathogen recognition and phagocytosis by neutrophils $[66,67]$.

Together, these findings indicate that BLV infection, particularly BLV-infected cows with $\mathrm{PL}$, may impact the outcome of intramammary infections because the resident milk neutrophils have an enormous impact on the elimination of bacteria by phagocytosis and the intracellular production of ROS $[36,56]$. Thus, we believe that BLV can affect mastitis control programs.

A feasible alternative to reduce the transmission of BLV infection could be achieved by eliminating animals with high proviral loads, which mainly exhibit PL instead of AL $[59,60]$. Thus, our findings regarding the milk neutrophil function in BLV-infected cows, particularly those with $\mathrm{PL}$, indicated that the elimination of PL animals may also lead to a lower probability of comorbidities, such as mastitis, which is regarded as the most costly dairy cattle disease and is thus associated with important economic and public health implications.

No perturbations in the percentages of $\mathrm{T}$ lymphocyte subsets among the milk cells from the BLV-infected cows were found, as was previously described for the peripheral blood of BLV-infected cows [4,6], although no consensus exists $[2,3,8]$. It is generally accepted that the infected cells (mainly B cells) frequently co-express CD5 and CD11b molecules [1,6]. Conversely, the present study shows an increase in the percentage of $\mathrm{CD}^{-} /$ $\mathrm{CD}_{11 b^{-}} \mathrm{CD}^{2} 1^{+}$cells (mainly B-1b cells) in the milk of BLV-infected cows, particularly those with PL. Although this observation is puzzling, it may lend insight into the roles of CD5 [68] and CD11b [69] on B cells in mammary gland immunity.

BLV infection is correlated with the inhibition of the apoptotic process, leading to the generation of a reservoir of apparently latent cells [1]. This phenomenon, together with the $\mathrm{B}$ cell tropism of BLV, may explain the lower percentage of milk B cells that was observed in the BLV-infected cows, particularly those with PL, that were undergoing apoptosis, which has been previously described for $\mathrm{B}$ cells that were obtained from blood $[1,16,18,19,21,22]$.

In conclusion, the present study provides novel insight into the implications of BLV infections for mammary 
gland immunity, which is mainly supported here by the dysfunction of the milk neutrophils. Thus, this study highlights the importance of controlling BLV infections due to their indirect effects, such as the higher susceptibilities of BLV-infected cows to secondary diseases, such as mastitis, which is the most costly disease affecting cattle.

\section{Abbreviations}

BLV: Bovine leukemia virus; ROS: Reactive oxygen species; MFI: Median fluorescence intensity; PL: Persistent lymphocytosis; SCC: Somatic cell count; AGID: Agar gel immunodiffusion; AL: Aleukemic; PBS: Phosphate-buffered saline; PE-Cy5: Phycoerythrin-Cy5; FITC: Fluorescein isothiocyanate: PE: Phycoerythrin; APC: Allophycocyanin; mAb: Monoclonal antibody; Ab: Antibody; PI: Propidium iodide; DCFH-DA: 2',7'-dichlorofluorescein diacetate; DCFH: 2',7'-dichlorofluorescein; CD62L: L-selectin; CD11b: $\beta$-chain of $\beta_{2}$-integrin; IFN- - : Interferon- $\gamma$.

\section{Competing interests}

The authors declare that they have no competing interests.

\section{Authors' contributions}

AMMPDL designed the experiments, supervised the studies and drafted and edited the manuscript. MGB designed the experiments, performed all of the analyses and edited the manuscript. FNS designed the experiments, performed all of the analyses and drafted the paper. BPS and CFB participated in the flow cytometric analysis. EMRS provided technical help, supervised the studies and edited the manuscript. LFFA collected all of the samples and provided technical help. SAD, JPH and MXS performed the statistical analyses and edited the manuscript. All authors read and approved the final manuscript.

\section{Authors' information}

Alice MMP Della Libera and Fernando N Souza should be considered co-first authors.

\section{Acknowledgments}

The authors are grateful for the financial support of the São Paulo State Research Foundation (Project number 2009/50672-0). We thank Claudia Regina Stricagnolo for her technical support.

\section{Author details}

'Departamento de Clínica Médica, Faculdade de Medicina Veterinária e Zootecnia, Universidade de São Paulo, Av. Prof. Dr. Orlando Marques de Paiva, 87, Cidade Universitária, São Paulo 05508-270, Brazil. ${ }^{2}$ Departamento de Medicina Veterinária Preventiva, Escola de Veterinária, Universidade Federal de Minas Gerais, Belo Horizonte 31270-010, Brazil. ${ }^{3}$ Laboratório de Sorologia e Imunobiologia, Instituto de Medicina Tropical, Universidade de São Paulo, São Paulo 05403-000, Brazil.

Received: 20 May 2014 Accepted: 26 November 2014

Published online: 17 January 2015

\section{References}

1. Gillet N, Florins A, Boxus M, Burteau C, Nigro A, Vandermeers F, Balon $H_{\text {, }}$ Bouzar AB, Defoiche J, Burny A, Reichert M, Kettman R, Willems L: Mechanisms of leukomogenesis induced by bovine leukemia virus: prospects for novel anti-retroviral therapies in human. Retrovirology 2007, 4:18.

2. Williams DL, Amborski GF, Davis WC: Enumeration of T and B cells lymphocytes in bovine leukemia virus-infected cattle, using monoclonal antibodies. Am J Vet Res 1988, 49:1098-1103.

3. Gatei MH, Brandon RB, Naif HM, Mclennan MW, Daniel RCW, Lavin MF: Changes in B cell and T cell subsets in bovine leukaemia virus-infected cattle. Vet Immunol Immunopath 1989, 23:139-147.

4. Taylor BC, Stott JL, Thurmond MA, Picanso JP: Alteration in lymphocyte subpopulations in bovine leukosis virus-infected cattle. Vet Immunol Immunopath 1992, 31:35-47.

5. Wu D, Takahashi K, Liu N, Koguchi A, Makara M, Sasaki J, Goryo M, Okada K: Distribution of T-lymphocyte subpopulation in blood and spleen of normal cattle and cattle with enzootic bovine leukosis. J Comp Pathol 1999, 120:117-127.
6. Della Libera AMMP, Blagitz MG, Batista CF, Latorre $A O$, Stricagnolo $C R$, Souza FN: Quantification of B cells and T lymphocytes subsets in bovine leukemia virus infected dairy cows. Semin-Cienc Agrar 2012, 33:1487-1494.

7. Ikebuchi R, Konnai S, Okagawa T, Yokoyama K, Nakajima C, Suzuki Y, Murata S, Ohashi K: Blockade of bovine PD-1 increases T cell function and inhibits bovine leukemia virus expression in B cells in vitro. Vet Res 2013, 44:59.

8. Suzuki $S$, Konnai $S$, Okagawa $T$, Ikebuchi R, Shirai T, Sunden $Y$, Mingala CN, Murata S, Ohashi K: Expression analysis of Foxp3 in T cells from bovine leukemia virus infected cattle. Microbiol Immunol 2013, 57:600-604

9. Rademacher R, Sodomkova D, Vanasek J: Alkaline phosphatase in neutrophil granulocytes of the peripheral blood of healthy and leukotic cattle. Vet Med (Praha) 1977, 22:673-677 (in German).

10. Walker AF, Lumsden JH, Stirtzinger T: Neutrophil function in sheep experimentally infected with bovine leukemia virus. Vet Immunol Immunopathol 1987, 14:67-76.

11. Takamatsu H, Inumaru S, Nakajima H: Inhibition of in vitro immunocyte function by sera from cattle with bovine leukosis. Vet Immunol Immunopathol 1988, 18:349-359.

12. Flaming KP, Frank DE, Carpenter S, Roth JA: Longitudinal studies of immune function in cattle experimentally infected with bovine immunodeficiency virus and/or bovine leukemia virus. Vet Immunol Immunopathol 1997, 56:27-38.

13. Kaczmarczyk E, Bojarojc-Nosowicz B, Fiedorowicz A: Leukocyte acid phosphatase and metabolic efficiency of phagocytes in the first lactation trimester of cows from a leukaemic herd. J Appl Genet 2005, 46:59-67.

14. Souza FN, Blagitz MG, Latorre AO, Ramos Sanchez EM, Batista CF, Weigel RA, Rennó FP, Sucupira MCA, Della Libera AMMP: Intracellular reactive oxygen production by polymorphonuclear leukocytes in bovine leukemia virusinfected dairy cows. J Vet Med Sci 2012, 74:221-225.

15. Schwartz-Cornil I, Chevallier N, Belloc C, Rhun DL, Lainé V, Berthelemy M, Mateo A, Levy D: Bovine leukaemia virus-induced lymphocytosis in sheep is associated with reduction of spontaneous B cell apoptosis. J Gen Virol 1997, 78:153-162.

16. Cantor GL, Pritchard SM, Dequiet F, Willems L, Kettman R, Davis WC: CD5 is associated from the $B$-cell receptor in $B$ cells from bovine leukemia virus-infected, persistently lymphocytotic cattle: consequences to B-cell receptor-mediated-apoptosis. J Virol 2001, 75:1689-1696.

17. Debacq C, Asquith B, Reichert M, Burny A, Kettmann R, Willems L: Reduced cell turnover in bovine leukemia virus-infected persistently lymphocytotic cattle. J Virol 2003, 77:13073-13083.

18. Takahashi M, Tajima S, Takeshima S-N, Konnai S, Yin SA, Okada K, Davis WC, Aida Y: Ex vivo survival of pheripheral blood mononuclear cells in sheep induced by bovine leukemia vírus (BLV) mainly occurs in $\mathrm{CD}^{-}$B cells that express BLV. Microb Infect 2004, 6:584-595.

19. Florins A, Gillet N, Asquith B, Boxus M, Burtheau C, Twizere J-C, Urbain P, Vandermeers F, Debacq C, Sanchez-Alcaraz MT, Schwartz-Cornil I, Kerkhofs P, Jean G, Thewis A, Hay J, Mortheux F, Wattel E, Reichert M, Burny A, Kettmann R, Bangham C, Willems L: Cell dynamics and immune response to BLV infection: an unifying model. Front Biosci 2007, 12:1520-1531.

20. Florins A, Boxus M, Vandermeers F, Verlaeten O, Bouzar A-B, Defoiche J, Hubaux R, Burny A, Kettmann R, Willems L: Emphasis on cell turnover in two hosts infected by bovine leukemia virus: a rationale for host susceptibility to disease. Vet Immunol Immunopathol 2008, 125:01-07.

21. Erskine RJ, Corl CM, Gandy JC, Sordillo LM: Effect of infection with bovine leucosis virus on lymphocyte proliferation and apoptosis in dairy cattle. Am J Vet Res 2011, 72:1059-1064.

22. Souza FN, Latorre AO, Caniceiro BD, Sakai M, Kieling K, Blagitz MG, Della Libera AMMP: Apoptosis of $\mathrm{CD}^{+}$cells and lymphocyte proliferation in bovine leukemia virus-infected dairy cows. Ara Bras Med Vet Zoot 2011, 63:1124-1130.

23. Emanuelson U, Scherling K, Pettersson H: Relationship between herd bovine leukemia virus infection status and reproduction, disease incidence, and productivity in Swedish dairy herds. Prev Vet Med 1992, 12:121-131.

24. Rusov V, Milojevic Z, Stojanovic L: Occurence of mastitis and sanitaryhygienic quality of milk of cows infected with enzootic leukosis. Vet Glasnik 1994, 48:303-308.

25. Sandev N, Koleva M, Binev R, llieva D: Influence of enzootic bovine leukosis virus upon the incidence of subclinical mastitis in cows at a different stage of lactation. Vet Arch 2004, 74:411-416. 
26. Jacobs RM, Pollari FL, McNab B, Jefferson B: A serological survey of bovine syncytial in Otario: Associations with bovine leukemia and immunodeficiency-like viruses, production records, and management practices. Can J Vet Res 1995, 59:271-278.

27. Yoshikawa H, Xie B, Otamada T, Hiraga A, Yoshikawa T: Detection of bovine leukemia viruses (BLV) in mammary tissues of BLV antibody-positive cows affected by subclinical mastitis. J Vet Med Sci 1997, 59:301-302.

28. Wellenberg GJ, Van der Poel WHM, Van Oirschot JT: Viral infections and bovine mastitis: a review. Vet Microbiol 2002, 88:27-45.

29. Bojarojc-Nosowicz B, Kaczmarczyk E: Somatic cell count and chemical composition of milk in naturally BLV-infected cows with different phenotypes of blood leukocyte acid phosphatase. Arch Tierz 2006, 49:17-28.

30. Rinaldi M, Li RW, Capuco AV: Mastitis associated transcriptomic disruptions in cattle. Vet Immunol Immunopathol 2010, 138:267-279.

31. Da Y, Shanks RD, Stewart JA, Lewin HA: Milk and fat yields decline in bovine leukemia virus-infected Holstein cattle with persistent lymphocytosis. Proc Natl Acad Sci U S A 1993, 90:6538-6541.

32. Sargeant JM, Kelton DF, Martin SW, Mann ED: Associations between farm management practices, productivity, and bovine leukemia virus infection in Ontario dairy herds. Prev Vet Med 1997, 31:211-221.

33. D'Angelino JL, Garcia M, Birgel EH: Productive and reproductive performance in cattle infected with bovine leukosis virus. J Dairy Res 1998, 65:693-695.

34. Ott $\mathrm{SL}$, Johnson R, Wells SJ: Association between bovine-leukosis virus seroprevalence and herd-level productivity on US dairy farms. Prev Vet Med 2003, 61:249-262.

35. Erskine RJ, Bartlett PC, Byrem TM, Render CL, Febvay C, Houseman JT: Association between bovine leukemia virus, production, and population age in Michigan dairy herds. J Dairy Sci 2012, 95:727-734.

36. Paape MJ, Bannerman DD, Zhao X, Lee JW: The bovine neutrophil: structure and function in blood and milk. Vet Res 2003, 34:597-627.

37. Rainard P, Riollet C: Innate immunity of bovine mammary gland. Vet Res 2006, 37:369-400.

38. Elazar S, Gone E, Livneh-Kol I, Rosenshine I, Sphigel NY: Essential role of neutrophils but not mammary gland alveolar macrophages in a murine model of acute Escherichia coli mastitis. Vet Res 2010, 41:53.

39. Souza FN, Ramos Sanchez EM, Heinemann MB, Gidlund MA, Reis LC, Blagitz MG, Della Libera AMMP, Cerqueira MMOP: The innate immunity in bovine mastitis: the role of pattern-recognition receptors. Am J Immunol 2012, 8:166-178.

40. Blagitz MG, Souza FN, Santos BP, Batista CF, Parra AC, Azevedo LFF, Melville PA, Benites NR, Della Libera AMMP: Function of milk polymorphonuclear neutrophils leukocytes in bovine mammary glands infected with Corynebacterium bovis. J Dairy Sci 2013, 96:3750-3757.

41. Schepers AJ, Lam TJGM, Schukken YH, Wilmink JBM, Hanekamp WJA: Estimation of variance components for somatic cell counts to determine threshold for uninfected quarters. J Dairy Sci 1997, 80:1833-1840.

42. Schukken YH, Wilson DJ, Welcome F, Garrison-Tikofsky L, Gonzales RN: Monitoring udder health and milk quality using somatic cell counts. Vet Res 2003, 34:579-596.

43. Divers TJ, Peek SF: Rebhunn's diseases of dairy cattle. St. Louis: Saunders Elsevier; 2008

44. Thurmond MC, Carter RL, Picanso JP, Stralka K: Upper-normal prediction limits of lymphocyte count for cattle not infected with bovine leukemia virus. Am J Vet Res 1990, 51:466-470.

45. Oliver SP, González RN, Hogan JS, Jayarao BM, Owens WE: Microbiological procedures for the diagnosis of bovine udder infection and determination of milk quality. Verona: National Mastitis Council; 2004

46. Piepers S, De Meulemeester L, de Kruif A, Opsomer G, Barkema HW, De Vliegher S: Prevalence and distribution of mastitis pathogens in subclinically infected dairy cows in Flanders, Belgium. J Dairy Res 2007, 74:478-483.

47. Piepers S, De Vliegher S: Oral supplementation of medium-chain fatty acids during the dry period supports the neutrophil viability of peripartum dairy cows. J Dairy Res 2013, 80:309-318.

48. Koess C, Hamann J: Detection of mastitis in the bovine mammary gland by flow cytometry at early stages. J Dairy Res 2008, 75:225-232.

49. Piepers S, De Vliegher S, Demeyere K, Lamrecht BN, de Kruif A, Meyer E, Opsomer G: Technical note: flow cytometric identification of bovine milk neutrophils and simultaneous quantification of their viability. J Dairy Sci 2009, 92:626-631.
50. Hasui M, Hirabayashi Y, Kobayashi Y: Simultaneous measurement by flow cytometry of phagocytosis and hydrogen peroxide production of neutrophils in whole blood. J Immunol Methods 1989, 117:53-58.

51. Diez-Fraile A, Meyer E, Paape MJ, Burvenich C: Analysis of the selective mobilization of L-selectin and Mac-1 reservoirs in bovine neutrophils and eosinophils. Vet Res 2003, 34:57-70.

52. Trainin Z, Brenner J, Meirom R, Ungar-Waron H: Detrimental effect of bovine leukemia virus (BLV) on immunological state of cattle. Vet Immunol Immunopathol 1996, 56:39-51.

53. Marinho J, Galvão-Castro B, Rodrigues LC, Barreto ML: Increased risk of tuberculosis with human T-lymphotropic virus-1 infection. J Acquir Defic Syndr 2005, 40:625-628.

54. Verdonck K, González E, Schrooten W, Vanham G, Gotuzzo E: HTLV-1 is associated with history of active tuberculosis among family members of HTLV-1 infected patients in Peru. Epidemiol Infect 2008, 136:1076-1083.

55. Vanleeuwen JA, Haddad JP, Dohoo IR, Keefe GP, Tiwari A, Scott HM: Risk factors associated with Neospora caninum seropositivity in randomly samples Canadian dairy cows and herds. Prev Vet Med 2010, 93:129-138.

56. Mehrzad J, Duchateau L, Burvenich C: Viability of milk neutrophils and severity of bovine coliform mastitis. J Dairy Sci 2004, 87:4150-4162.

57. Van Oostveldt K, Paape MJ, Dosogne H, Burvenich C: Effect of apoptosis on phagocytosis, respiratory burst and CD18 adhesion receptor expression of bovine neutrophils. Domest Anim Endocrinol 2002, 22:37-50.

58. Mehrzad J, Duchateau L, Burvenich C: High milk neutrophi chemiluminescence limits the severity of bovine coliform mastitis. Vet Res 2005, 36:101-116.

59. Juliarena MA, Gutierrez SE, Ceriani C: Determinationof proviral load in bovine leukemia virus-infected cattle with and without lymphocytosis. Am J Vet Res 2007, 68:1220-1225.

60. Alvarez I, Gutiérrez G, Gammella M, Martinez C, Politzki R, González C, Caviglia L, Carignano H, Fondevila N, Poli M, Trono K: Evaluation of total white blood cell count as a marker for proviral load of bovine leukemia virus in dairy cattle from herds with a high seroprevalence of antibodies against bovine leukemia virus. Am J Vet Res 2013, 74:744-749.

61. Yakobson B, Brenner J, Ungar-Waron H, Trainin Z: Cellular immune response cytokine expression during initial stage of bovine leukemia virus (BLV) infection determines the disease progression to persistent lymphocytosis. Comp Immunol Microbiol Infect Dis 2000, 23:197-208.

62. Ikebuchi R, Konnai S, Shirai T, Sunden Y, Murata S, Onuma M, Ohashi K Increase of cells expressing PD-L1 in bovine leukemia virus infection and enhancement of anti-viral immune responses in vitro via PD-L1 blockade. Vet Res 2011, 42:103.

63. Okagawa T, Konnai S, Ikebuchi R, Suzuki S, Shirai T, Sunden Y, Onuma M, Murata S, Ohashi K: Increased bovine Tim-3 and its ligand expressions during bovine leukemia virus infection. Vet Res 2012, 43:45.

64. Sordillo LM, Babiuk LA: Modulation of bovine mammary gland function during the periparturient period following in vitro exposure to recombinant bovine intereferon gamma. Vet Immunol Immunopathol 1991, 27:393-402.

65. Gonen E, Nedvetzki S, Naor D, Shpigel NY: CD44 is highly expressed on milk neutrophils in bovine mastitis and plays a role in their adhesion to matrix and mammary epithelium. Vet Res 2008, 39:29.

66. Vachon E, Martin R, Plumb J, Kwok V, Vandivier W, Glogauer M, Kapus A, Wang X, Chow C-W, Grinstein S, Downey GP: CD44 is a phagocytic receptor. Blood 2006, 107:4149-4158.

67. Sladek Z, Rysanek D: Expression of macrophage CD44 receptor in the course of experimental inflamammatory response of bovine mammary gland induced by lipopolysaccharide and muramyl dipeptide. Res Vet Sci 2009, 89:235-240.

68. Berland $\mathrm{R}$, Wortis $\mathrm{HH}$ : Origins and functions of $\mathrm{B}-1$ cells with notes of the role of CD5. Annu Rev Immunol 2002, 20:253-300.

69. Kawai K, Tsuno NH, Matsuhashi M, Kitayama J, Osada T, Yamada J, Tsuchiya T, Yoneyama S, Watanabe T, Takahashi K, Nagawa H: CD11b-mediated migratory property of peripheral blood B cells. J Allergy Clin Immunol 2005, 16:192-197. 